\title{
Cuatro compositores románticos
}

\section{Four romantic composers}
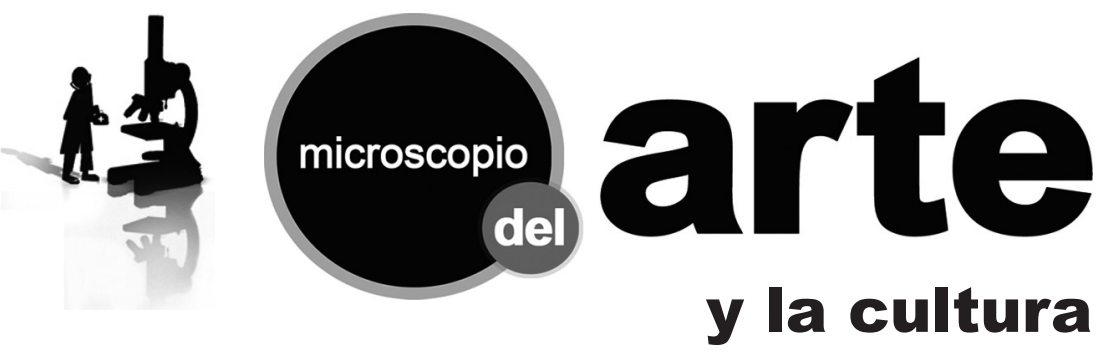

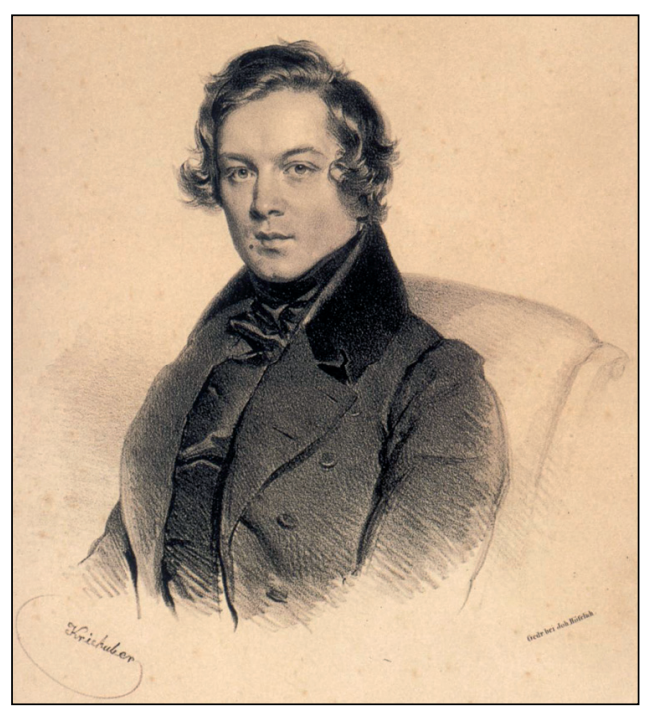

Figura 1. Robert Schumann en 1839, litografía por Joseph Kriehuber.

$\mathrm{E}$ 1 romanticismo surge a finales del siglo dieciocho como una fuerza arrolladora y vital, destinada a expresar el espíritu de rebeldía y libertad que dominó el pensamiento y la creatividad artística de la primera mitad del siglo diecinueve.

El artista romántico dejó de ser un empleado de reyes y príncipes, su arte dejó de ser mero elemento decorativo o de entretención para pasar a expresar los sentimientos humanos, sus conflictos, y la belleza de la naturaleza.

En una época de ascenso de la burguesía industrial y mercantil pero aún dominada por el poder de la monarquía, el romanticismo pareció ser el último soplo de frescura antes de la llegada de la revolución industrial y la proletarización de las grandes masas.

En la música, los precursores tempranos los encontramos en Beethoven, von Weber y Schubert, compositor romántico por excelencia, perseguidor de un ideal de amor y belleza imposibles, tanto en sus hermosas lieder como en la vida real, fallecido de fiebre tifoidea y en la pobreza a la temprana edad de treinta y siete años.

Otros cuatro compositores ocuparon el centro del romanticismo musical del siglo diecinueve. Todos tuvieron un brillo intenso

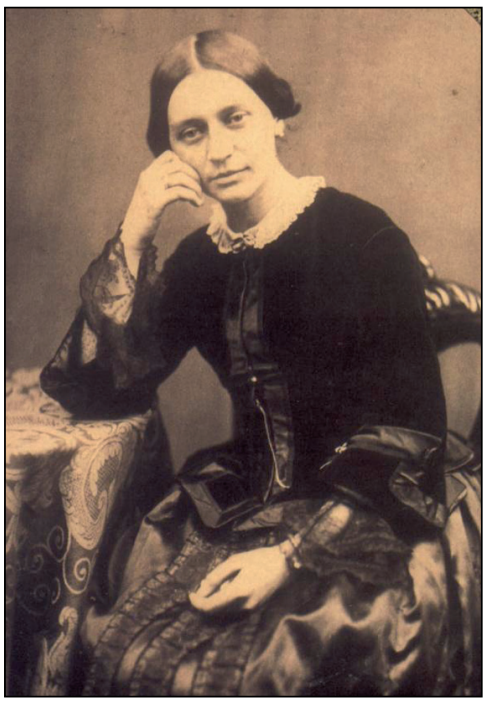

Figura 2. Clara Schumann en 1853, fotografía anónima. pero breve, y sus vidas compartieron las vicisitudes del artista romántico, incluyendo las enfermedades emblemáticas de la época: la tuberculosis y la sífilis.

Nacieron prácticamente al mismo tiempo: Felix Mendelssohn nació en 1809 en Hamburgo; Robert Schumann en 1810 en Zwickau, Alemania; Frederic Chopin también en 1810 cerca de Varsovia, y Franz Liszt en 1811 en Raiding, Hungría.

Excepto Liszt, que vivió hasta los setenta y cinco, los demás fallecieron jóvenes: Mendelssohn a los treinta y ocho años, Chopin a los treinta y nueve, y Schumann a los cuarenta y seis.

Felix Mendelssohn era el único que provenía de una familia acomodada; pero eso no impidió que llevara una vida agitada, trashumante e intensa, según el ideal romántico.

Fundó y dirigió, junto a Schumann, el conservatorio de Leipzig, el que llegó a ser el principal centro de formación musical de Alemania.

Por su parte, Chopin desarrolló su carrera de compositor y pianista en París, donde mantuvo una intensa relación amorosa con Aurore Lucile Dupin, baronesa de Dudevant, escritora conocida con el seudónimo de Georges Sand.

Franz Liszt ha sido considerado el más grande intérprete del piano, y también residió en París; a su casa llegaban Victor Hugo, Héctor Berlioz, Chopin, Schumann y Niccolò Paganini. Al parecer tenía cierta debilidad por las mujeres casadas y nobles, pues vivió con la condesa Marie d'Agoult con quién tuvo tres hijos, y posteriormente con la princesa Carolyne Sayn-Wittgenstein que también estaba casada.

De los cuatro, Robert Schumann fue quizás el que llevó una vida más intensa y trágica. A diferencia de sus compañeros, amó intensamente a una sola mujer: la pianista Clara Wieck, con quién se casó luego de varios años de agrias disputas con su familia, que se oponía al matrimonio. Para ella compuso las "Escenas de infancia" una de las más hermosas piezas para piano. Viajaron juntos por Europa, mientras Clara ejecutaba las piezas escritas por su esposo. Hacia 1844, Schumann comenzó a padecer episodios de depresión y alucinaciones, lo que lo llevaría a intentar suicidarse arrojándose al Rhin, de donde es rescatado, y posteriormente internado en un asilo, donde fallece en brazos de Clara en julio de 1856.

Aquí entra en escena un quinto músico, que podría haber formado parte del grupo anterior pero que nació veinte años después. Se trata de Johannes Brahms.

Cuando Schumann fue internado y dejó a Clara sola a cargo de sus siete hijos, el joven Brahms se fue a vivir a su casa y cuidaba de la familia cuando ella salía en sus giras de concierto. Tímido y sensible, posiblemente amó en silencio a la mujer de su maestro y cuando ésta yacía moribunda, compuso las desgarradoras "Cuatro canciones serias".

Johannes Brahms falleció el 3 de abril de 1897, un año después que Clara Schumann.

\section{Referencias}

1. Grey Anne: Breve guía de la música clásica. Javier Vergara editor. Buenos Aires, 1995

2. Enciclopedia Hispánica: Encyclopaedia Britannica Publishers,Inc. Versailles Kentucky, 1994.

Las fotografias son de dominio público.

Ernesto Payá G 